\title{
Antitrust regulation as a stimulant innovation processes in the agricultural sector
}

\author{
Marina Anisimova ${ }^{1, *}$, Aleksey Ruchkin ${ }^{2}$, Ekaterina Kot $^{2}$, and Tatyana Rakhlis ${ }^{3}$ \\ ${ }^{1}$ Ural State University of Economics, 620144 Ekaterinburg, Russia \\ ${ }^{2}$ Ural state agrarian University, Institute of Economics, Finance and Management, 620075 \\ Yekaterinburg, Russia \\ ${ }^{3}$ Nosov Magnitogorsk State Technical University, 455000 Magnitogorsk, Russia
}

\begin{abstract}
The article is devoted to the problems of formation of favorable competitive environment in the domestic seed market, reducing the dependence of the domestic market on foreign breeding and genetic materials. The aim of the study is to substantiate new requirements for anti-monopoly regulation of intellectual property in agricultural markets to level out risks to competition. Theoretical basis of the study consists of the publications of modern domestic and foreign scientists on the assessment of risks of restricting access to innovative products and technologies for potential competitors, the development of competition at different levels of the food supply chain. The processes of companies' consolidation at the world seed market and control of the market by the players with intellectual property rights to biotechnologies were reflected. The expediency of development of antitrust regulation in the sphere of intellectual property in the domestic seed market through technological transfer of innovative material to Russian companies is shown. Theoretical significance of the conducted study consists in development of some approaches to anti-monopoly regulation in the sphere of intellectual property in the domestic seed market. The practical significance of the study lies in improving the management of innovation process in the agricultural sector.
\end{abstract}

\section{Introduction}

The most important priority of the country's agricultural sector is to ensure food independence, as well as to provide the population with safe, quality and affordable agricultural products, raw materials and food. Anti-monopoly instruments are one of the measures of the state agricultural policy aimed at creating a favourable competitive environment, overcoming the dependence of the domestic market on foreign breeding and genetic materials and related agricultural technologies.

Modern trends in economic development are characterized by increasing competitive tensions in commodity markets, including agricultural markets, the formation of specific

\footnotetext{
* Corresponding author: Anisimova1@usue.ru
} 
forms of competition due to the ownership and disposal of intangible assets. A company's monopoly position based on the enshrining of intellectual property rights means that it gains protection from competition through the use of exclusive rights in the product. The abuse of exclusive rights has an impact on business costs and food prices.

Intellectual property in the knowledge economy is a critical resource for leadership. Intellectual property is contradictory: on the one hand, it protects innovators' ideas and helps them to commercialise their achievements, but on the other hand, it blocks innovative development by limiting companies' access to knowledge and information. The current intellectual property regime is in the interest of intellectual property-exporting countries. Industrialised countries and transnational corporations possess large amounts of intellectual property, retain control over technical advances and profit through exclusive rights.

Intellectual property in agriculture has been shaped by the development of a special regime for the protection of breeding achievements. However, as a result of the authorisation of biotechnology patents by most countries, genetic resources have rapidly become proprietary. This trend has contributed to a change in the agribusiness model involving the widespread use of highly productive plant varieties created by modern microbiology techniques. Thus, the Russian seed market is currently characterised by an underdeveloped in-house seed industry (seed production and processing and breeding activities), high dependence on imported seed supplies for certain crops and on foreign high-tech solutions in crop production. Processes to localise domestic seed production in the territory are very slow and limited to the establishment of seed processing or multiplication facilities. With an integrated approach to seed marketing, including patent and biological protection, foreign companies have an advantage in the seed market.

There are significant risks in the established structure of the seed market, which in the long term threatens the food security of the country. The most important new market trend is the increasing consolidation of companies, control of the market of global seed supply by three players with intellectual property rights to genetic and biotechnologies that ensure crop yields [1]. With Russia's agro-markets dependent on gene technology, domestic agribusiness cannot compete with global seed companies without access to such technology.

The study is an attempt to substantiate the position to the approach of anti-monopoly regulation of intellectual property in order to level out the risks to competition in the agromarkets of the country, which served as the basis for choosing the topic of the article and determined the range of tasks to be solved.

\section{Research methodology and methods}

The research was based on the publications of modern domestic and foreign scientists on the issues of antitrust regulation of agricultural markets, assessment of risks of restricting access to innovative products and technologies for potential competitors, development of competition at different levels of the food supply chain. I. Lianos and C. Lombardi made a significant contribution to the development of theoretical and practical issues of expanding intellectual property rights in the food supply chain [1]. Modern aspects of the development of competition in the global seed market are reflected in the work of I. Lianos, D. Katalewski, A. Ivanov [2]. The links between innovation, food system transformation and technology implementation are revealed in the studies of T. Reardon, L. Lu, D. Zilberman [3]. However, the issues related to the development of tools for anti-monopoly regulation of intellectual property in Russian agro-markets require closer attention.

The methodological basis of the study was a systematic approach using the analytical method. The information basis of the study was the data of the Federal Antimonopoly Service of Russia. 


\section{Results}

Anti-monopoly regulation and intellectual property rights are considered by specialists to be the initiator of innovation processes. Their targeting of innovations, which are based on dynamic competition, is noted [4].

Intellectual property rights are initially an exception to the rules of competitive markets in Russia. In economic and legal scientific literature there is an active discussion on the formation of general principles of interaction between competition law and intellectual property rights. The results of scientific discussion allow to speak about different points of view on the expediency of antimonopoly regulation of intellectual property rights as a new institution of innovation and competition development.

Critics of the interference of competition law with intellectual property rights often point out the peculiarities of different intellectual property objects and justify the need to form anti-monopoly practices for each of them. In addition, the intervention of competition law in the sphere of intellectual property turnover will, in their opinion, slow down the process of creation of research units by large companies in Russia, worsen the integration of advanced plant technologies into Russian practice and the conditions for Russian business access to innovations [6]. Analyzing the state of the entrepreneurial climate in various countries, a number of specialists point out that the application of antitrust rules to the circulation of intellectual property rights will increase the level of uncertainty for companies in terms of choosing norms and rules of doing business and forming algorithms of actions [7]. Among the reasons negatively affecting the process of antimonopoly regulation of innovation, the slowdown of innovation development, unjustified interference of administrative mechanisms are mentioned [8].

The overwhelming majority of academic economists and lawyers do not see competition law as a major threat to innovation in the economy, their starting point being that there is no intrinsic conflict between intellectual property rights and competition rules. Some authors suggest a complete reorientation of competition law towards a more dynamic approach that would include innovation as a goal of competition law [9].

This discussion highlights not only the importance of intellectual property law

intellectual property and competition law, but also the complexity of the various tradeoffs that need to be made between competition and technological innovation. Intellectual property rights, like competition, are necessary to promote innovation and ensure its competitive use, in particular to reduce the dependence of the domestic market on foreign breeding and genetic material and to level out risks to competition in the Russian market. It is necessary to develop a reasonable concept of anti-monopoly regulation of competition in the field of intellectual activity, which will allow to rethink the interaction of competition law with intellectual property rights, to move to the standards of economic balance of their interaction. The accumulated experience of regulation by the Russian antimonopoly authorities will allow to make weighted decisions on the cases, initiated on the grounds of violation of the antimonopoly legislation.

An important area for the development of antimonopoly regulation in the sphere of intellectual property on the domestic seed market is to ensure competition through the technological transfer of innovative material to Russian companies in order to strengthen their competitiveness. The national approach to solving the problem of the correlation between antitrust regulation and intellectual property rights will significantly reduce the control of domestic agribusinesses by global companies - rights holders of molecular breeding agents. The method of technological transfer relies on foreign experience that confirms the effectiveness of antitrust measures [10].

The method of technological transfer of breeding tools to Russian companies in order to create conditions for the development of potential competition on the part of domestic 
agribusinesses was implemented by FAS Russia in the framework of the prescription issued on the acquisition by Bayer AG (Germany) of more than $50 \%$ of the voting shares of Monsanto Company (USA) [11-13]. A specific feature of the prescription is its comprehensive nature, taking into account both the transfer of innovative material to agricultural enterprises with significant success in breeding work, and the training of Russian specialists in modern methods of accelerated breeding. The Russian Federal Antimonopoly Service's order provides for the creation of a unique advanced plant biotechnology training and research centre in Russia. We believe that the establishment of subdivisions of this centre in the regions will accelerate the training of specialists who need to acquire or deepen the basic knowledge and skills underlying modern molecular breeding technologies. Practice-oriented training of Russian specialists in modern techniques will strengthen the role of Russian breeding.

At present, the competitive position of seed companies in the market is increasing, not only due to the possession of rights to genetic technologies, but also as a result of the takeover of companies owning genetic information. With agribusinesses dependent on genetic technologies to improve crop yields, it is important to ensure their access to such technologies. This is possible by looking at economic concentration transactions through the lens of the global food supply and value chain, rather than as a set of stand-alone markets.

\section{Discussion and Conclusion}

The need for import substitution in the domestic seed industry is due to the high dependence on imported supplies of genetic materials and seeds. To improve the situation in this sphere, state support for the creation of agro-genetics centres is required, and the application of competition law to the practice of abusing intellectual property rights as a tool to monopolize agricultural markets. Merger of companies causes significant competition risks for the Russian seed market.

The complex legal and biological environment of the seed industry turns part of the value chain into a closed system that relies on specific contracting methods. Proprietary biological instruments owned by a limited number of seed companies increase the control of the seed industry. A business environment based on intellectual property makes it difficult to promote the principles of open access to innovation for domestic agribusinesses.

Since innovation is the main driver of economic growth, public authorities have a direct role in supporting the creation of an innovation-friendly market environment. The importance of the competitive process in promoting innovation is well known and widely recognised. The development of effective anti-monopoly instruments will help to counteract the negative effects on competition in the seed market resulting from the abuse of intellectual property rights. The complexity of solutions stems from the need to take into account the different interests of actors in the food supply chain.

\section{References}

1. I. Lianos, C. Lombardi, Concurrences Review 1, 78014, 22-35 (2016)

2. I. Lianos, D. Katalevsky, A. Ivanov, Concurrences Review 2, 78807, 62-80 (2016)

3. T. Reardon, Lu.L. Liang, D. Zilberman, Food Policy, 83, 285-288 (2019) DOI:10. 1016/j.foodpol.2017.10.003

4. J. Drexl, Research Handbook on Intellectual Property and Competition Law, 512 (Edward Elgar Publ., 2008) 
5. A.B. Kashevarov, Parallel import: pros and cons URL: http //fas.gov.ru/system/presentations/attachments/2016/04/20/original (reference date: 21.02.2021).

6. N. Voznesensky, A. Muravin, Russian Competition Law and Economy 3(9), 36 - 41 (2013)

7. Y. Katsoulacos, D. Ulph, International Journal of Industrial Organization 41(2), 255282 (2016)

8. A.A. Kurdin, A.E. Shastitko, State and municipal government issues, 1, 31 - 49 (2017)

9. I. Lianos, Global Food Value Chains and Competition Law BRICS Draft Report, University College London - Faculty of Law; BRICS Competition Law \& Policy Centre - HSE National Research University, 1039 (2017)

10. T. Riis, Journal of Intellectual Property Law \& Practice, 6(7), 482-493 (2011) DOI:10.1093/jiplp/jpr050.

11. Final Report to the Enlarged Meeting of the Collegium of the Federal Antimonopoly Service of Russia on 6 October 2020 URL: https://fas.gov.ru/documents/687358 (reference date: 21.02.2021).

12. V. Vikulina, Corporate economy, 2(22), 25-32 (2020)

13. T.V. Zyryanova, S.B. Zyryanov, Agrarian Bulletin of the Urals, 11(153), 99-101 (2016) 